\title{
GSTT2 wt Allele
}

National Cancer Institute

\section{Source}

National Cancer Institute. GSTT2 wt Allele. NCI Thesaurus. Code C158389.

Human GSTT 2 wild-type allele is located in the vicinity of $22 q 11.23$ and is approximately $4 \mathrm{~kb}$ in length. This allele, which encodes glutathione S-transferase theta-2 protein, plays a role in glutathione metabolism. 